\title{
Synthesis and cytotoxicity assay using Brine Shrimp Lethality Test of Cinchonidine Isobutyrate Ester
}

\author{
Mario $^{1 *}$, Puspa D.N.Lotulung ${ }^{2}$, Gian Primahana ${ }^{2}$, Sylvia Rizky Prima ${ }^{1}$ and Muhammad Hanafi ${ }^{2}$ \\ ${ }^{1}$ Faculty of Pharmacy, Univesity of 17 Agustus 1945, North Jakarta, Indonesia \\ ${ }^{2}$ Research Center for Chemistry, Indonesian Institute of Sciences, Kawasan Puspiptek, Serpong, Indonesia \\ *Corresponding author: marioshine0412@gmail.com
}

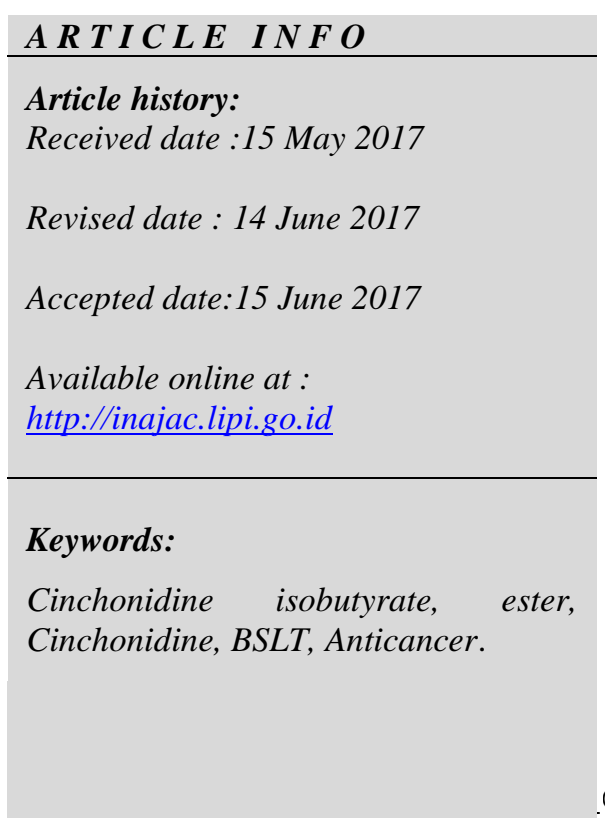

\begin{abstract}
This research was aimed to synthesize cinchonidine isobutyrate ester and conduct a preliminary assay for anticancer agent using cytotoxicity assay to Artemia salina Leach larva, or also known as brine shrimp lethality test (BSLT). Cinchonidine, a compound that has quinoline rings and quiniclidine ring, is a quinine analogue and stereoisomer of cinchonine. Cinchonidine is predicted to have anticancer activity. Synthesized ester was aimed to gain higher lipophilicity. Higher lipophilicity makes it easier for the compund to pass through cell membrane. The esterification process used DMAP as a catalyst, DCC as an activator, and isobutyric acid as a carboxilyc acid. Isobutyric acid is a type of short chained fatty acid that usually acts as an anticancer prodrugs. The product is identified by ESI-MS, FT-IR, ${ }^{1} \mathrm{H}-\mathrm{NMR}$, dan ${ }^{13} \mathrm{C}-\mathrm{NMR}$. Ester cinchonidine isobutyrate is gelatinous and colourless with yield of $21,77 \%$. BSLT result showed that cinchonidine isobutyrate ester had $\mathrm{LC}_{50}$ value of $75.16 \mathrm{ppm}$ which was more toxic than cinchonidine that had $\mathrm{LC}_{50}$ value of $99.2 \mathrm{ppm}$. It was proved that higher lipophilicity could increase pharmacology activity.
\end{abstract}

(C) 2017 Indonesian Journal of Applied Chemistry. This is an open access article under the CC BY-NC-SA license.

\section{INTRODUCTION}

Cancer is a degenerative disease caused by abnormal cell growth and can spread and invade normal cells in the body. Cancer is one of the biggest causes of death in the world [1] (This encouraged the researchers to seek new chemo preventive agent with low systemic toxicity effects to minimize the occurrence of cancer therapy failure [2].

The ring of quinolone compounds has identified to have anti-cancer activity in addition to antimalarial and antiinflammatory [3]. Compounds that have quinolone ring such as quinine and its derivation has an effect on phase schizoints parasites and help take it out of the circulation. This compound also has the nature of gametocytocidal in Plasmodium vivax and $P$. malariae [4]. In addition, quinine and its derivatives also produce autophagy which is the process of solving the intracellular component through lysosome [5].

The autophagy ability could indicate cytotoxic properties of the compound. Quinacrine (quinine derivatives) can cause cell death via autophagy through the increase of p53 and p21 [6]. It was reported that quinine and its derivatives also had anticancer activity on breast, colon, lung, and glioma [7]. Quinine and its derivatives can also serve as triggers for apoptosis to MCF-7 cells [8]. Quinine and its derivations have reached phase III clinical trial [9]. Beside quinine, cinchonine had also been reported to 


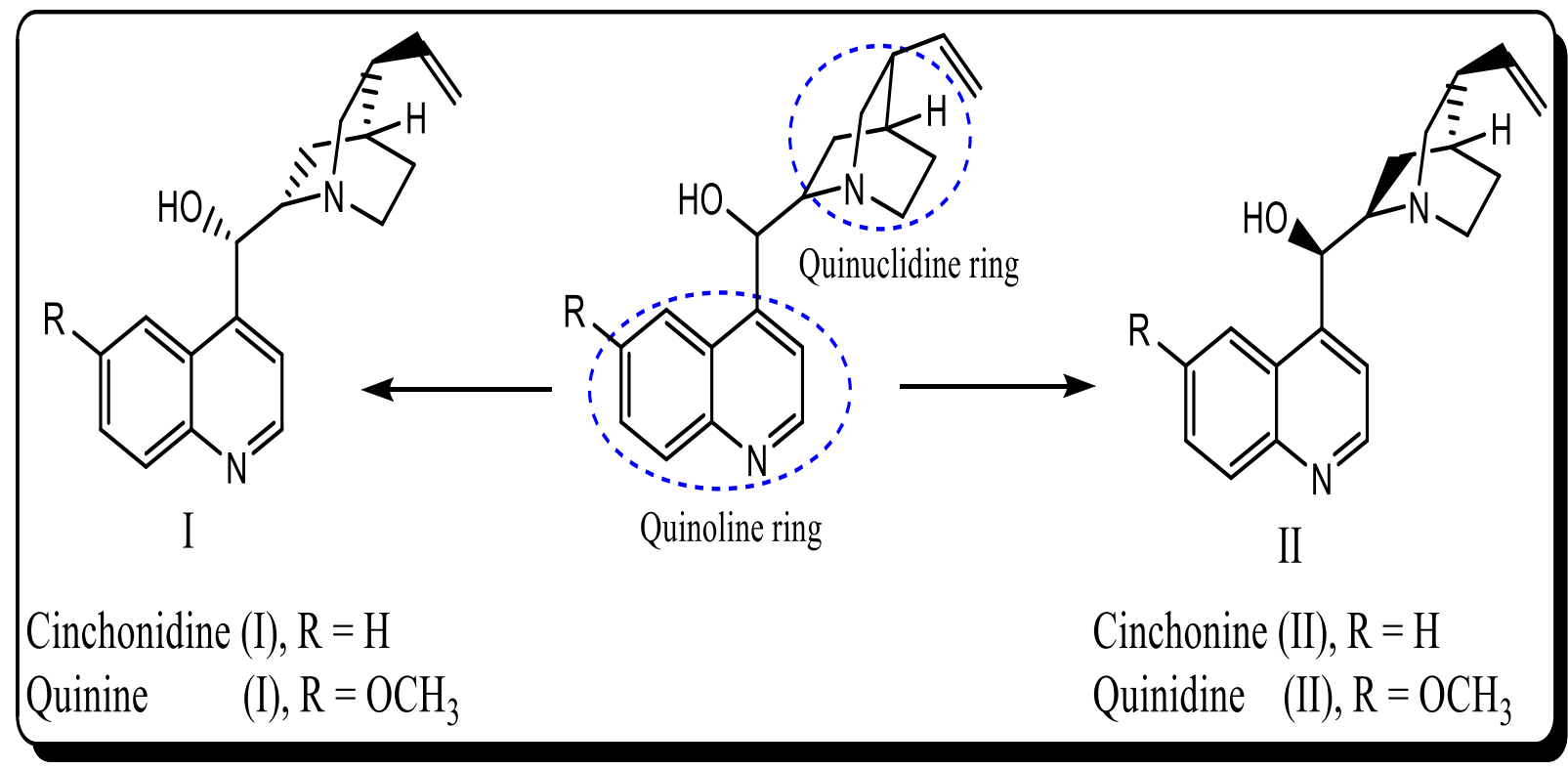

Fig 1. Cinchona alkaloid and their basic skeleton.

have cytotoxic properties against Chinese hamster ovary cancer cells (CHO) [10].

Cinchonidine, a compound that has quinolone ring, is a quinine analogue and stereoisomer of cinchonine [11] so that it is predicted have activity against cancer cells. Cinchonidine has also been observed to have non-toxic activity against normal fibroblast cells. On the other words, it is more selective than quinine [12].

Synthesis of esters using isobutyric acid was based on 3 reasons: it forms an ester prodrugs for the purpose of reaching the target and it is readily hydrolyzed [13], it is easily conducted on cinchonidine [14] and it has the right properties for anticancer drugs with special mechanisms and low toxicity [15].

The creation of this synthesis is also based on the Lipinski rule concerning the parameters of drug compounds that have an absorption or permeability. Cinchonidine isobutyrate was predicted by ChemDraw application to have $\log \mathrm{P}$ value 4.05 , molecular weight $364.22,4$ hydrogen bond acceptors, and no hydrogen bond donor, exactly as described in the Lipinski rule.

It became the base for synthesis of cinchonidine isobutyrate esther. The toxicity value to artemia salina $L$ larva was 30 | "Synthesis and cytotoxicity assay ....": Mario, et.al conducted using brine shrimp lethality test (BSLT) method.

\section{EXPERIMENTAL SECTION}

\section{1. Materials}

Cinchonidine was obtained from Local supplier (PT. Sinkona Indonesia Lestari Indonesia), while isobutiryc acid and other materials for BSLT method were from sigma. All solvent chemicals used were of technical grade and redistilled before use. Compounds were identified with FT-IR, NMR, and ESIMS.

\section{2. Methods}

\section{2. 1. Synthesis of Cinchonidine Isobutyrate}

Cinchonidine (588.7 $\mathrm{mg}, 2 \mathrm{mmol}$ ) was dissolved with dichloromethane and added with $211.94 \mathrm{mg}$ of butyric acid and 412.66 $\mathrm{mg}$ of DCC. They were stirred vigorously for 1 hour. Later, the mixture was added with DMAP (30.628 mg) followed by continuous stirring for overnight. After that, DCU formed was filtered off and washed with $\mathrm{NaHCO} 3$. Crude extracts were purified over flash silica column chromatography using ethyl acetate $100 \%$. 


\section{2. 2. Identification of compounds}

Compounds were identified using Thin Layer Chromatography continued with spectrophotometer, NMR, FT-IR, and mass spectrometry.

\section{2. 3. Hatching eggs Artemia salina Leach.}

Eggs of Artemia shrimp were submerged in water for 15-30 minutes. After that, the eggs were hatched in $10 \mathrm{~L}$ of water or water soluble synthetics with composition of 38 grams of pure salt in $1 \mathrm{~L}$ of water for 24 hours, covered with aluminum foil. Hatching temperature and $\mathrm{pH}$ were controlled. Hatching temperature was $25 \mathrm{C}^{\circ}-30 \mathrm{C}^{\circ}$ and $\mathrm{pH}$ was set at $\pm 6-7$. The eggs were incubated during 18-24 hours and the larvae were ready for the test after 48 hours (Subyakto, 2003).

\section{2. 4. BSLT Method}

Cinchonidine $100 \mathrm{mg}$ and Cinchonidine isobutyrate were diluted until the concentration reached $10 \mu \mathrm{g} / \mathrm{ml}, 100 \mu \mathrm{g} / \mathrm{ml}$, $500 \mu \mathrm{g} / \mathrm{ml}$, and $1000 \mu \mathrm{g} / \mathrm{ml}$. The control solution was also prepared (3 replicates). Serial solutions were transferred into 96-well microplates that contains the $3 \mathrm{ml}$ sea water and 10 larvae shrimp and left for 24 hours. The results were analyzed to generate LC50 values [13].

Data from probit number were put into a table. The $\mathrm{X}$-axis was percentage of the larvae death and the $\mathrm{Y}$-axis was $\log$ concentration.

\section{$\%$ Larvae mortality $=$}

(number of dead larvae)/(number of larvae of the experiment) $\times 100 \%$

After that, the results of the analysis were placed into the table and the results of the regression of $\mathrm{Y}=\mathrm{A}+\mathrm{BX}$. $\mathrm{LC}_{50}$ Value is obtained by entering the value $\mathrm{y}=50$, then the value of $\mathrm{LC}_{50}$ was retrieved.

\section{RESULT AND DISCUSSION}

\section{1. Identified with spectrofotometer}

The molecular weight of cinchonidine isobutyrate was 364.22 , based on the results of a spectrum of ESI-MS that showed $\mathrm{m} / \mathrm{z}$ : 365.89 (Figure 2).

Identification of cinchonidine isobutyrate using FTIR showed peaks on $1734.01 \mathrm{~cm}^{-1}$ for $-\mathrm{C}=\mathrm{O}$ esther. Meanwhile, - $\mathrm{CO}$ - esther was characterized by the presence of a peak from 1190,08 $\mathrm{cm}^{-1}$ from -CO- esther bond. Figure 3 ensured that there was no spectrum - $\mathrm{OH}$ of cinchonidine or - $\mathrm{OH}$ from isobutiryc acid.

Spectra of ${ }^{1} \mathrm{H}-\mathrm{NMR}$ data of cinchonidine isobutyrate (Figure 4) indicated the presence of two methyl groups of isobutyrate ( 3 "\& $4 ")$ at $\delta 1.14(\mathrm{~d})$ and 1.19 (d) methin oxy $(\mathrm{H}-9)$ became downfield at $\delta 6.50 \mathrm{ppm}(\mathrm{d}, 1$ $\mathrm{H}$ ), indicating that chinconidine had been esterified. The other signal indicated the presence of vinyl at $\delta 5,0 \mathrm{ppm}$, some aromatic protons at $\left.\delta 7.38 \mathrm{ppm}\left(\mathrm{d}, \mathrm{H}-3^{\prime}\right) \mathrm{H}\right)$, 7.59, ppm (t, H-6'),H, 7.71, ppm (t, H-7'), 8.12 (d, H-8'), 8.24 (d, H-8') and 8.88 ppm (d, H-2"). Chemical shift data ${ }^{1} \mathrm{H}-\mathrm{NMR}$ was supported with spectrum of ${ }^{13} \mathrm{C}-\mathrm{NMR}$ demonstrating that cinchonidine isobutyrate had been synthesized. Spectrum of ${ }^{13} \mathrm{C}$ NMR (Figure 5) also showed the presence of isobutyrate at $\delta 18.3$ (C-3"), $19.0 \mathrm{ppm}$ (C-4"), C-2" 34.3 (C-2") and $176.0 \mathrm{ppm}$. The presence of aromatic ring was shown at $\delta$ 118.7 (C-5'), 123.5 (C-3'), 126.15, 127.0 (C-6'), C-7' 129.3 (C-7') 130.6 (C-8'), 148.7 (C-2'), $150.0 \quad$ (C-4') ppm. 


\section{pp. 29-35, June 2017}

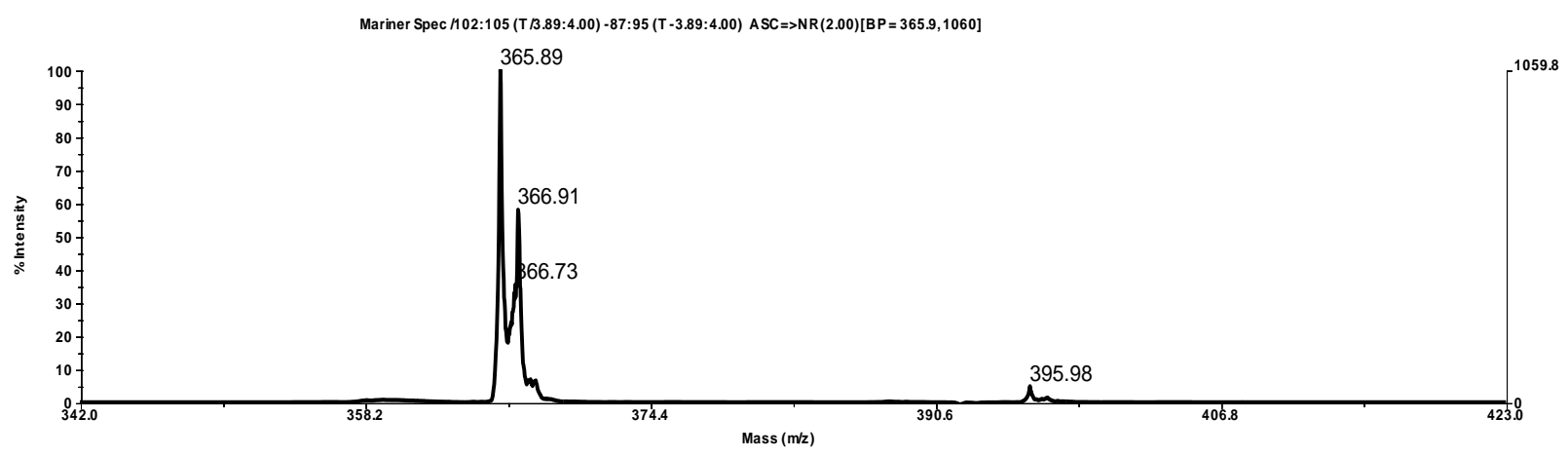

Fig. 2. The Spectrum of ESI-MS.

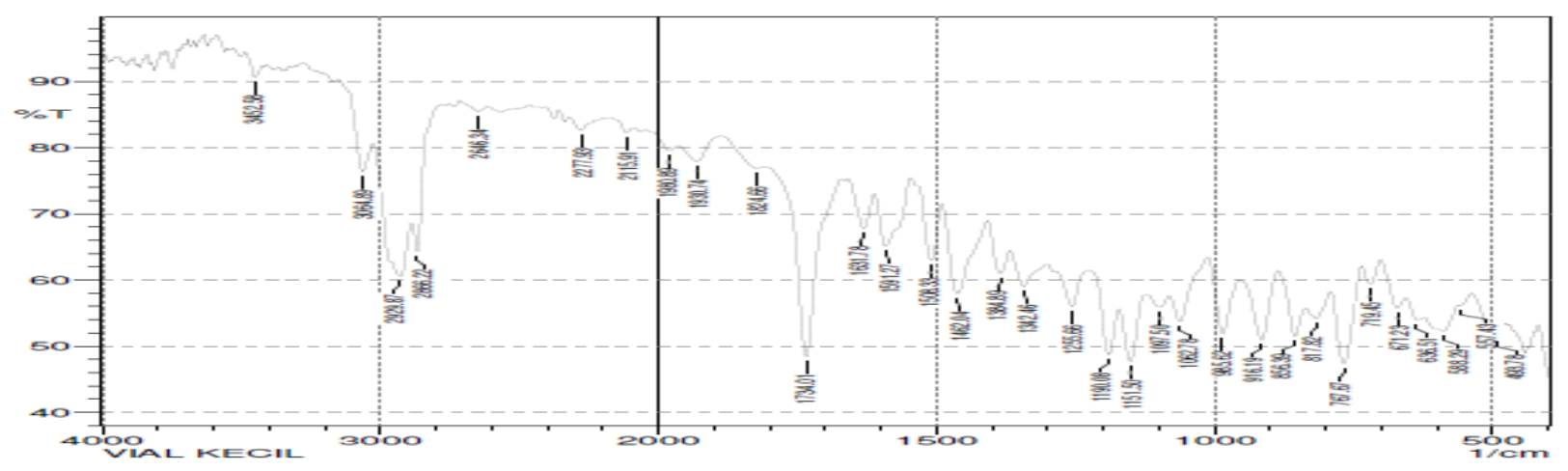

Fig. 3. FT-IR spectra of Cinchonidine Isobutyrate esther.

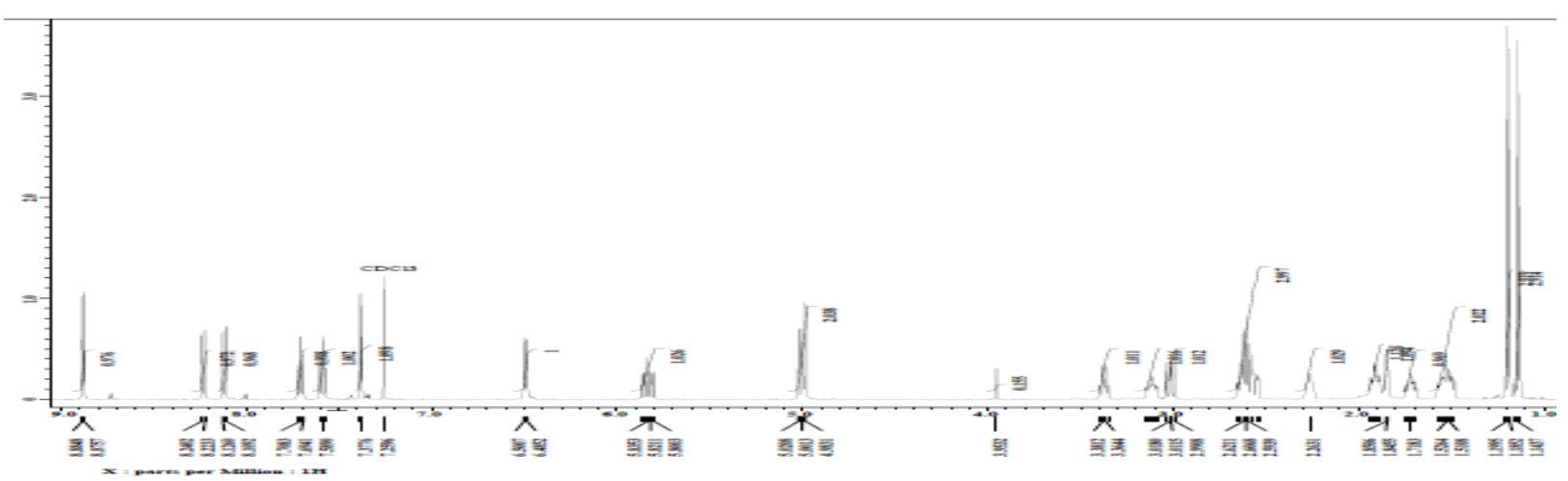

Fig. 4. Spektra ${ }^{1}$ H-NMR.

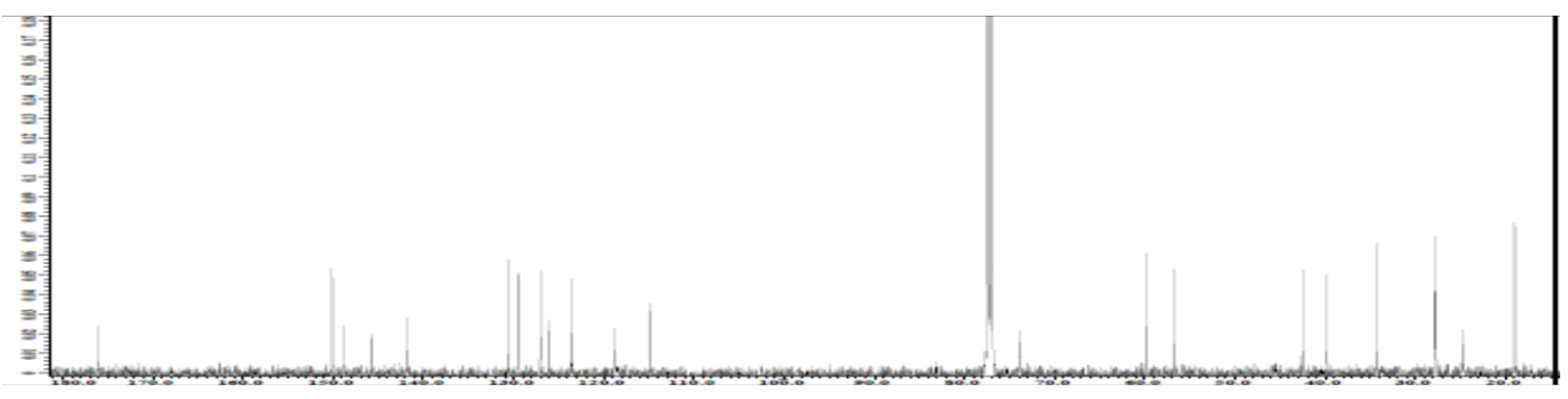

Fig. 5. Spektra ${ }^{13 '} \mathrm{C}-\mathrm{NMR}$ 
pp. 29-35, June 2017

Table 1. Toxicity Test Result of BSLT for cinchonidine and cinchonidine isobutyrate $\left(\mathrm{LC}_{50}\right)$

\begin{tabular}{|l|c|c|c|c|c|c|c|c|c|}
\hline \multicolumn{1}{|c|}{ Sample } & $\begin{array}{c}\text { C } \\
(\mathbf{p p m})\end{array}$ & Log K & \multicolumn{2}{|c|}{ Surviving } & $\begin{array}{c}\text { Mortality/ } \\
\text { Surviving }\end{array}$ & $\begin{array}{c}\text { Total } \\
\text { Mortality/ } \\
\text { Surviving }\end{array}$ & $\begin{array}{c}\text { Mortality } \\
(\%)\end{array}$ & $\begin{array}{c}\text { LC } \\
\text { ( ppm) }\end{array}$ \\
\hline Blanko & & & 10 & 10 & 10 & & & & \\
\hline $\begin{array}{l}\text { Ester sinchonidin } \\
\text { isobutyrate }\end{array}$ & 10 & 1,0 & 4 & 3 & 2 & $21 / 9$ & $21 / 50$ & 29.58 & 75.6 \\
\hline & 100 & 2,0 & 10 & 9 & 10 & $1 / 29$ & $22 / 41$ & 34,92 & \\
\hline & 500 & 2,7 & 3 & 5 & 4 & $18 / 12$ & $40 / 12$ & 76,92 & \\
\hline & 1000 & 3,0 & 0 & 0 & 0 & $30 / 0$ & $70 / 0$ & 100,00 & \\
\hline Sinchonidine & 10 & 1,0 & 10 & 10 & 10 & $3 / 27$ & $3 / 49$ & 5,77 & 99.2 \\
\hline & 100 & 2,0 & 10 & 10 & 10 & $7 / 23$ & $10 / 23$ & 31,25 & \\
\hline & 500 & 2,7 & 11 & 10 & 10 & $31 / 0$ & $41 / 0$ & 100,00 & \\
\hline & 1000 & 3,0 & 10 & 10 & 10 & $30 / 0$ & $71 / 0$ & 100,00 & \\
\hline
\end{tabular}

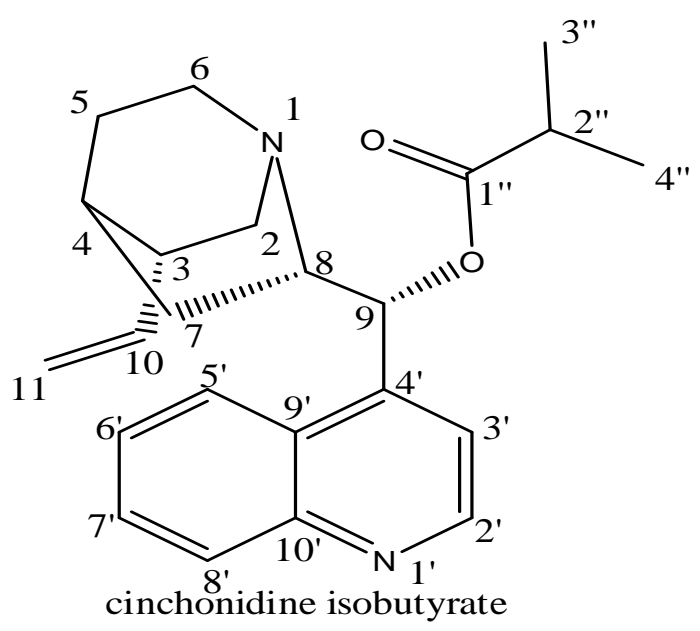

Fig. 6. Structure of Cinchonidine Isobutyrate.

3. 2. The toxicity test against Artemia Larvae Saline Leach with Brine Shrimp Lethality Test method (BSLT)

Cinchoninidine is a derivate of cinchona alkaloids. Cinchonidine had quinclidine and quinolone rings that have affinities on receptors for instance breast cancer cells MCF-7 [14,23]. Cinchonidine isobutyrate esther had specifications as required by the Lipinski rule, which is having molecular weight $\leq 500, \log \mathrm{P} \leq 5$, bond the donor of $\mathrm{H} \leq 5$, bond acceptors of $\mathrm{H} \leq 10$, and the number of atoms $\mathrm{N}$ and $\mathrm{O} \leq 10$ [12]. Cinchonidine isobutyrate had molecular weight $364.22, \log \mathrm{P} 4.05$, no ties to $\mathrm{H}$ donor $\mathrm{H}, 4 \mathrm{H}$ bond acceptors, only 2 atoms of $\mathrm{N}$ and 2 atoms of $\mathrm{O}$. The higher its lipophilicity, the easier it penetrates cell membranes. Lipophilicity Ascension Theory was also supported by the existing research that proved that modification of quinine with fatty acids resulted in more toxicity against FM3A cells, compared to quinine [6]. Beside to increase lipophilicity, the reason to synthesize esthers as prodrugs was because when esther had penetrated the membrane, then it could be easily hydrolyzed by enzymes and become active. The usual enzymes found in the blood, liver, and other tissues and organs like carboxylesterases, 
acetylcholinesterases, butyrylcholinesterases, paraoxonases arylesterases can hydrolyze ester into cinchonidine and isobutiryc acid $[10,18]$. Isobutyryc acids as short chain fatty acids are used as a combination of anticancer prodrugs that are the most commonly used and also non-toxic.

The results showed that the cinchonidine isobutyrate esther was more toxic than cinchonidine itself. Cinchonidine isobutyrate had $\mathrm{LC}_{50}$ of $75.56 \mathrm{ppm}$ whereas $\mathrm{IC}_{50}$ of cinchonidine was $98.83 \mathrm{ppm}$. Other studies were conducted to compare IC50 values of cinchonidine against parasites like Trypanosoma brucei brucei bloodstream forms, l. mexicana mexicana promastigotes, and a chloroquine-sensitive strains of Plasmodium falciparum (3D7) and WI38 (normal fibroblasts cells) find out its selectivity. The results showed that cinchonidine demonstrated high selectivity between fibroblast cells with a parasite [11]. This proved that cinchonidine was less harm than the others. Cinchonidine isobutyrate had not reached a good toxicity (LC50 $\leq 30$ ppm), but this experiment is referrable to the next research to increase more lipophilicity of cinchonidine with another acids or it should be tested on cancer cells in vitro.

\section{CONCLUSIONS}

The conclusion that can be resumed from this research was that the synthesis of cinchonidine isobutyrate could be done using DCC and DMAP for yield value of $27.7 \%$. It requires optimization to get higher yield. The toxicity test using Larval Shrimp BSLT method against Artemia salina Leach showed that cinchonidine isobutyrate esther had $\mathrm{LC}_{50}$ value of $75.16 \mathrm{ppm}$, indicating more toxicity than its original compound, cinchonidine with $\mathrm{LC}_{50}$ value of $99.2 \mathrm{ppm}$. It demonstrated that increasing lipophilicity could improve the pharmacological activity.

\section{ACKNOWLEDGEMENT}

We thank the faculties of Pharmacy University of 17 August 1945 for teaching us about Pharmacy and leadership and also staff of Research Center for Chemistry, Indonesian Institute of Sciences for helping us complete this study.

\section{REFERENCES}

[1]. Achan, J., Talisuna, A.O., Erhart, A., Yeka, A., Tibenderana, J.K., Baliraine, F.N., Rosen-thal, P.J., D'Alessandro, U., 2011. Quinine, an old anti-malarial drug in a modernworld: role in the treatment of malaria. Malar. J. 10, 144.

[2]. Beaumont, K., Webster, R., Gardner, I. \& Dack, K. Design of ester prodrugs to enhance oral absorption of poorly permeable compounds: challenges to the discovery scientist. Curr. Drug Metab. 4, 461-485 (2003).

[3]. Bredel, M. (2001). Anticancer drug resistance in primary human brain tumors. Brain Research.Brain Research Reviews, 35(2), 161-204.

[4]. Fessenden, R., \& Fessenden, J. S. (1991). Kimia Organik Edisi III jilid I (III). Massachuset: Penerbit Erlangga.

[5]. Kementrian Kesehatan RI Pusat Data dan Informasi Kesehatan. (2015). Stop Kanker. Infodatin-Kanker.

[6]. Kumura, N., Izumi, M., Jima, S. N., Shimizu, S., Kim, S., Wataya, Y., Aba, N. B. (2005). Synthesis and Biological Activity of Fatty Acid Derivatives of Quinine Synthesis and Biological Activity of Fatty Acid Derivatives of Quinine, 8451(October). http://doi.org/10.1271/bbb.69.2250

[7]. Kundu, C. N., Das, S., Nayak, A., Satapathy, S. R., Das, D., \& Siddharth, S. (2015). Anti-malarials are anticancers and vice versa - One arrow two sparrows. Acta Tropica, 149, 113-127. http://doi.org/10.1016/j.actatropica.201 5.03.028

[8]. Lai, J., Ma, Z., Mink, L., Mueller, L. J., \& Zaera, F. (2009). Influence of Peripheral Groups on the Physical and Chemical Behavior of Cinchona 
Alkaloids, 11696-

[9]. Lastenia RM,Wilfredo RM, Matias R, RafaelMD, Concepcion DI, Guadano A, Azucena GC. Bioactive cinchona alkaloids from Remijia peruviana. J Agric Food Chem 2005; 53: 19211926

[10]. Liederer, B. M. \& Borchardt, R. T. Enzymes involved in the bioconversion of ester-based prodrugs. J. Pharm.Sci. 95, 1177-1195 (2006).

[11]. Leverrier, A., Bero, J., Frédérich, M., Quetin-leclercq, J., \& Palermo, J. (2013). European Journal of Medicinal Chemistry Antiparasitic hybrids of Cinchona alkaloids and bile acids. European Journal of Medicinal Chemistry, 66, 355-363. http://doi.org/10.1016/j.ejmech.2013.0 6.004

[12]. Lipinski, C. A. (2004). Lead profiling Lead- and drug-like compounds: the rule-of-five revolution, 337-341. http://doi.org/10.1016/j.ddtec.2004.11. 007

[13]. Meyer, B. N., Ferrigni, N. R., Putnam, J.E., Jacobson, L. B., Nichols, D. E., and McLaughlin, J. L., (1982), Brine shrimp:a convenient general bioassay foractive plant constituents. Planta Medica, 45:31 34.

[14]. Mfan, S., Anand, K., Anandakumar, S., Singh, S., Chuturgoon, A. A., \& Gengan, R. M. (2016). Discipline of Medical Biochemistry, School of Laboratory Medicine and Medical Sciences, $J P B$. http://doi.org/10.1016/j.jphotobiol.2016 .10 .009

[15]. Mohapatra, P., Preet, R., Das, D., Satapathy, S.R., Choudhuri, T., Wyatt, M.D., Kundu,C.N., 2012. Quinacrinemediated autophagy and apoptosis in colon cancer cellsis through a p53- and p21-dependent mechanism. Oncol. Res. 20, 81-91.

[16]. Preet, R., Mohapatra, M., Das, D., Satapathy, S.R., Choudhuri, T., Wyatt,
M.D.,Kundu, C.N., 2012a. Lycopene synergistically enhances quinacrine action to inhibit Wnt-TCF signaling in breast cancer cells through APC. Carcinogenesis 34,277-286.

[17]. Preet, R., Mohapatra, P., Mohanty, S., Sahu, S.K., Choudhuri, T., Wyatt, M.D., Kundu,C.N., 2012b. Quinacrine has anticancer activity in breast cancer cells through inhibition of topoisomerase activity. Int. J. Cancer 130, 1660-1670.

[18]. Rautio, J., Kumpulainen, H., Heimbach, T., \& Oliyai, R. (2008). Prodrugs : design and clinical applications, 7 (march), 255-270. http://doi.org/10.1038/nrd2468

[19]. Rephaeli, A., Zhuk, R., \& Nudelman, A. (2000). Prodrugs of Butyric Acid From Bench To Bedside: Synthetic Design , Mechanisms of Action , and Clinical Applications, 391, 379-391.

[20]. Sarita Saraswati, Abdulqader, A., and Alhaider, S.S. 2013. Agrawal Anticarcinogenic effect of brucine in diethylnitrosamine initiated and phenobarbital - promotedhepato carcinogenesis in rats. ChemicoBiological Interactions; 206 (2013) 214-221.

[21]. Sanda, \& Radu, R. (2012). Contribution to cinchona alkaloids chemistry, 1-46.

[22]. Schlesinger, P.H., Krogstad, D.J., Herwaldt, B.I., 1988. Antimalarial agents: mecha-nisms of action. Antimicrob. Agents Chemother. 32, 793-798.

[23]. Wu, D. 2003. Studies on novel heterocyclic compounds and their microbicidal efficacy. Tetrahedron. 59, 8649-8687

[24]. Zhang, M., \& Wilkinson, B. (2007). Drug discovery beyondthe"rule-offive."

http://doi.org/10.1016/j.copbio.2007.10 